\title{
Childhood asthma along the United States/ Mexico border: hospitalizations and air quality in two California counties
}

\author{
Paul B. English, ${ }^{1}$ Julie Von Behren, ${ }^{2}$ Martha Harnly, ${ }^{2}$ and \\ Raymond R. Neutra ${ }^{2}$
}

ABSTRACT Since the passage of the North American Free Trade Agreement in 1993, there has been an increasing need to monitor environmental health trends that may be related to the rapid industrialization of the United States/Mexico border. We studied two counties on the California/ Baja California border to obtain baseline data on trends in childhood asthma hospitalizations and two pollutants that aggravate asthma, ozone and particulate matter (less than 10 microns in diameter), from 1983 to 1994. Hospital discharge records of children 14 years and younger were analyzed, and rates by county, race, and sex were age-adjusted to the 1990 California population. Data on five ozone and particulate matter indices obtained from the California Environmental Protection Agency were used. Imperial County had the highest childhood asthma hospitalization rates in California for non-Hispanic whites and African-Americans, and the second highest for Hispanics. San Diego County had rates below the state average. Over the time period examined, rates in Imperial County increased 59\%, while those in San Diego County decreased 9\%. Maximum ozone levels increased $64 \%$ in Imperial County but decreased $46 \%$ in San Diego County. Particulate matter levels were four times higher in Imperial than in San Diego County. High rates of childhood asthma hospitalizations in Imperial County may be partially related to high levels of poverty and worsening air quality conditions produced by increased burdens on the local airshed. Asthma prevalence surveys and binational time-series analyses examining asthma-pollutant relationships are needed.

Asthma is the most common chronic disease among children in the United States of America (1) and the most common cause of childhood hospitalizations in the state of California (2). There has been growing concern in the U.S. and Mexico over asthma's high social costs and over the recent increases

1 Impact Assessment, Inc., Emeryville, California. Mailing address: Impact Assessment, Inc., 5900 Hollis St., Suite E, Emeryville, CA 94608, USA.

2 California Department of Health Services, Environmental Health Investigations Branch, Emeryville, California, USA. in morbidity and hospitalization rates in both countries. In the U.S., asthma prevalence increased 39\% among children under 18 years of age between 1981 and 1988 (3), and from 1980 to 1993 the annual hospitalization rate increased $28 \%$ among persons under 25 years of age (1). In Mexico, hospitalizations due to asthma increased from 10 to $140 / 100000$ between 1960 and 1988, and morbidity has been on the rise, especially among adolescents (4). In addition to a huge toll in decreased quality of life, asthma is responsible for enormous direct and in- direct monetary costs, estimated at US\$ 6.2 billion in 1990 alone (5).

Asthma, which is characterized by chronic inflammation and episodic obstruction of the airways leading to difficulty in breathing, is potentially fatal if untreated. The etiology of asthma is thought to be multifactorial, with environmental, genetic/familial, and socio-economic influences playing a role. Factors found to be related to observed increases in asthmatic symptoms include exposure to high levels of ambient air pollutants such as ozone and particulate matter; tobacco 
smoke; and allergens associated with cat dander, cockroaches, house dust mites, pollens, and molds $(3,6,7)$. Exposure to agricultural pesticides has been noted to aggravate asthmatic symptoms in farm workers (8).

The California/Baja California border has been the site of significant demographic and environmental changes over the last two decades. The urban areas of Tijuana, San Diego, and Mexicali and the agricultural border towns in the Imperial Valley have grown rapidly in the 1980s and 1990s. Tijuana's population has more than doubled, from 462000 in 1980 to over 1 million in 1995 (9). San Diego County grew $44 \%$ over the same time period, although its rate of expansion has slowed in the 1990s. Increased traffic, agricultural dust, and an expanding maquiladora industry have placed a substantial burden on the regional environment. The international border at San Ysidro, in San Diego County, California, is the site of 3.6 million crossings per month, more than anywhere else in the world (Millicent Cox, personal communication).

At the Calexico/Mexicali border in the Imperial Valley, truck crossings increased 44\% from 1991 to 1995 (10). The two California border counties, San Diego and Imperial, both fail to meet state standards for ambient ozone and particulate matter levels (11). Whether deterioration of ambient air quality, increases in traffic flow, and immigration of vulnerable populations into the border area are related to elevated asthma morbidity and hospitalizations is not known.

As part of a five-year study to examine sentinel health events at the California/Baja California border and their possible link to environmental quality and demographic changes, we examined trends in childhood asthma hospitalizations and air quality for San Diego and Imperial Counties from 1983 to 1994 . We attempted to answer the following questions: Did childhood asthma hospitalization rates increase during this period of rapid population growth? If so, which age and racial/ethnic groups had the highest risks? How did hospitalization rates in these counties compare with those in other California counties? Did levels of ambient air pollutants rise over the same time period?

\section{MATERIALS AND METHODS}

Computerized records of all 19831994 discharges from all hospitals in Imperial and San Diego Counties (except Federal facilities) were obtained from the California Office of Statewide Health Planning and Development (2). Children aged 14 and younger who were discharged with asthma as the primary diagnosis were identified based on the International Classification of Diseases, code 493 (12). Data on each child's age, sex, race/ethnicity, expected principal source of payment, and residential ZIP code, as reported by the hospital, were obtained for each discharge. A single individual could be represented by more than one hospital discharge.

Using the discharge data, annual hospitalization rates were calculated for the years 1983-1994 for boys and girls in four racial/ethnic groups (AfricanAmerican, non-Hispanic white, Hispanic, and others [Asians, Native Americans, unknown]) and three age groups $(<1,1-4$, and 5-14 years of age). Denominators for the rates were obtained from the population estimates of the California Department of Finance, Demographic Research Unit (13). To compare hospitalization rates in Imperial and San Diego Counties with those in other California counties, rates were combined for the years 1991-1994 in order to stabilize small numbers. Rates by county, racial/ethnic group, and sex were age-adjusted (using the three age categories) by the direct method to the 1990 California population as provided by the Department of Finance (14). The $95 \%$ confidence intervals (95\% CI) for the age-adjusted rates were computed using a square root transformation for Poisson distributed rates (15).

Ambient air quality data for Imperial and San Diego Counties for the years 1983-1994 were obtained from the California Air Resources Board (16). Ambient ozone and particulate matter less than 10 microns in diameter $\left(\mathrm{PM}_{10}\right)$ were examined because they are known to exacerbate asthma (6) and are the only two air pollutants that were continuously monitored in Imperial County over the study period. Ozone was monitored on an hourly basis at eight or nine sites in San Diego County and in one to three sites in Imperial County. The ozone monitoring sites in San Diego County were widely dispersed over coastal, inland, and downtown locations. In Imperial County only one monitor, located in El Centro (in the south-central part of the county), measured ozone from 1983 to 1990 . A new ozone monitor was added at the international border in each county in $1991 . \mathrm{PM}_{10}$ was sampled every sixth day for a 24-hour period at one to seven monitors in San Diego County and in one to six monitors in Imperial County. Additional $\mathrm{PM}_{10}$ monitors were added at the border in San Diego County in 1993 and in Imperial County in 1994. Particulate matter monitoring began in 1984 at sites in the north and south of each county.

Five annual air quality parameters were obtained for each county: the maximum and mean ozone levels (in parts per hundred million [pphm]), the average number of days in which ozone levels per monitor exceeded 12 pphm (Federal standard), the maximum average $\mathrm{PM}_{10}$ levels over a 24hour period, and the proportion of $\mathrm{PM}_{10}$ samples that exceeded $50 \mu \mathrm{g} / \mathrm{m}^{3}$ (California standard). Maximum levels of pollutants and the number of days exceeding standards were used as indicators of acute exposure. Due to the localized representativeness and high spatial variability of $\mathrm{PM}_{10}$ monitoring, county-wide averages of this pollutant were not computed. Annual average values for ozone were the average of all hourly observations from all monitors, and maximum values were the maximum recorded value at any one monitor for each year. As San Diego County had more monitoring stations than Imperial County and would thus be more likely to detect excess quantities of pollutant, the annual number of days exceeding 
standards per monitor was computed for ozone. Since the California standard for ozone changed in 1988, for the sake of consistency the Federal standard for ozone was used to compute the number of days standards were exceeded.

\section{RESULTS}

The two study counties are almost equal in physical size and share a common border with Mexico, yet they differ in their social and demographic characteristics. San Diego County has a predominantly white urban population of over 2.5 million. It is a relatively wealthy county, with some agricultural areas in the northern part and a diversifying economy. Imperial County has a rapidly growing population of 140000 and an agriculturallybased economy. Its population is mostly Hispanic and young, with high unemployment (28.8\% in 1995) and poverty rates (in 1989, 23.8\% of the population had incomes below the poverty line).

\section{Trends in annual childhood hospitalization rates}

Age-adjusted childhood asthma hospitalization rates in Imperial County were two to three times higher than rates in San Diego County and in the state of California as a whole throughout 1983-1994 (Figure 1). In each of these years, the San Diego County rates were significantly lower and the Imperial County rates were significantly lower than the rates for California as a whole. Over the same time period, age-adjusted childhood asthma rates increased $59 \%$ in Imperial County (from 439.2 to 699.5/100 000), while decreasing $9 \%$ in San Diego County (from 197.4 to $178.8 / 100000$ ) and $11 \%$ in the state of California (228.8 to 203.6/100 000). Most of the increase in Imperial County occurred in 1989-1994, with increases averaging $12 \%$ per year.

In both counties studied, children 1-4 years old had the highest asthma

FIGURE 1. Age-adjusted childhood asthma hospitalization rates and $95 \%$ confidence intervals $(95 \% \mathrm{Cl})$, California border counties, 1983-1994

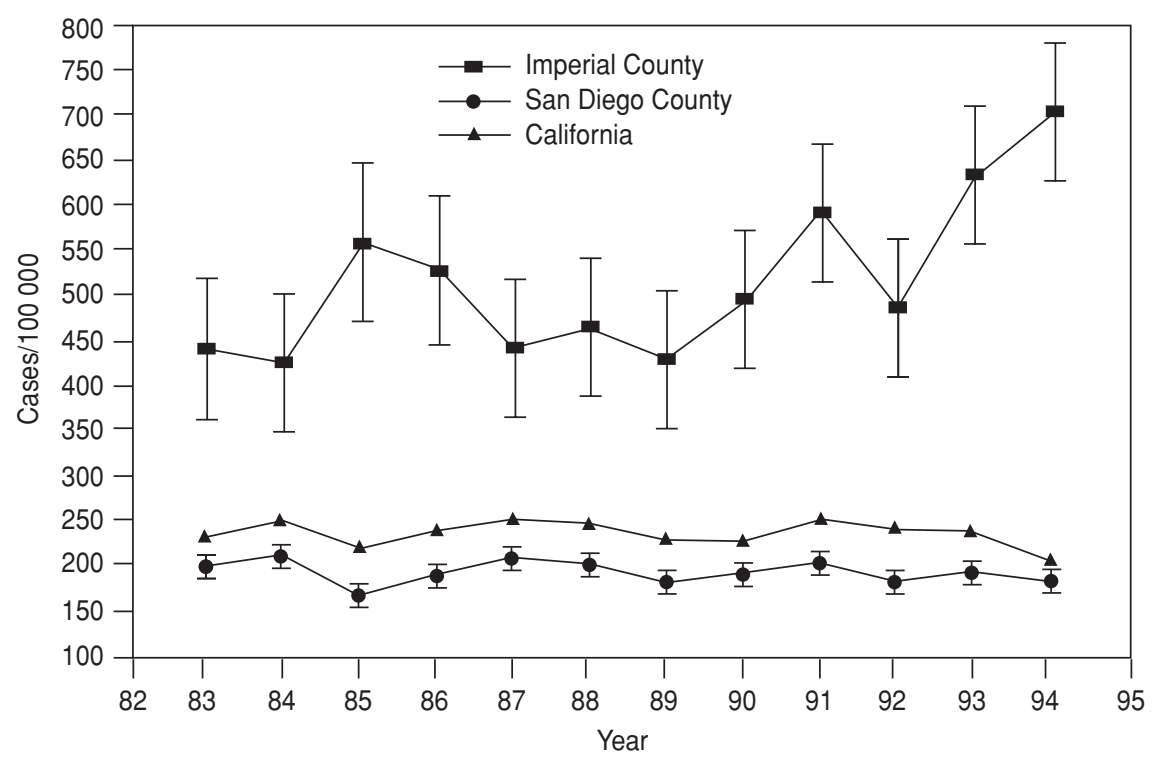

Sources: California Office of Statewide Planning and Development and California Department of Finance.

hospitalization rates. Between 1983 and 1994, the rate for this age group increased $71 \%$ in Imperial County (from 590.8 to $1010.0 / 100000$ ) but decreased $18 \%$ (from 352.4 to 288.8 / $100000)$ in San Diego County. Similarly, the asthma hospitalization rate among children aged 5-14 years of age increased $52 \%$ in Imperial County (from 365.5 to 555.3/100 000) over the time period and decreased $6 \%$ in San Diego County (from 134.6 to 126.5/ $100000)$. In contrast, the rates among infants $<1$ year old showed parallel trends in both counties, with an increase of $51 \%$ (from 466.9 to $703.5 /$ $100000)$ in Imperial County and of $46 \%$ in San Diego County (from 129.4 to $189.6 / 100000)$.

The race/ethnicity profile of childhood hospitalization rates differed in the two border counties. In Imperial County, non-Hispanic white and Hispanic children had similar age-adjusted rates in 1983, but the small gap between them widened steadily throughout the years under study. The rate among Hispanics decreased 36\% (from 562.0 to $357.5 / 100000$ ), while the non-Hispanic white rate doubled (from 615.0 to $1262.7 / 100000$ ). Rates for African-American and other races were not computed on an annual basis in Imperial County due to small numbers. In San Diego County, the rates for children of non-Hispanic white, Hispanic, and other races were similar, except that African-American children had rates two to three times higher. From 1983 to 1994, asthma hospitalization rates for non-Hispanic white and Hispanic children decreased 19\% (from 183.8 to $149.8 / 100000$ ) and $6 \%$ (from 142.9 to $133.7 / 100000)$, respectively. In the same period, hospitalization rates for African-American children in San Diego County increased 36\% (from 450.1 to $610.1 / 100000$ ).

Following U.S. trends, male children were more likely to be hospitalized with asthma than were female children in both counties. In San Diego County, age-adjusted rates for both sexes decreased from 1983 to 1994, with a decrease of $9 \%$ among males (from 243.2 to $221.4 / 100000)$ and of $10 \%$ among females (from 148.8 to $134.2 / 100000$ ). In Imperial County, rates increased 
$50 \%$ for males (from 586.4 to 881.5 / 100000 ) and $77 \%$ for females (from 286.2 to $507.3 / 100000)$.

Combined asthma childhood hospitalization rates for 1991-1994 revealed that Imperial County had the highest or second highest rate in California for the three racial/ethnic categories examined. For non-Hispanic whites, Imperial County had a rate of 924 cases per $100000(95 \% C I=807$ to 1048$)$, the highest in the state and five times the state average (185/100 000), while San Diego County had a rate close to the median for all California counties, $167 / 100000(95 \% C I=160$ to 175$)$. For Hispanics, the rate in Imperial County was $522 / 100000(95 \% C I=481$ to 565$)$, the second highest in the state, while San Diego County had a rate of 152/ $100000(95 \% C I=143$ to 161$)$, significantly below the state average (187/ $100000)$. For African-Americans, Imperial County had the highest rate in the state $(1667 / 100000 ; 95 \% C I=1200$ to $2210 ; n=42)$, and San Diego County had a rate of $423 / 100000(95 \% \mathrm{CI}=393$ to 453$)$, significantly below that of the entire state (704/100 000).

Examination of expected source of payment for 1994, the last year for which data were analyzed, showed that children with a diagnosis of asthma at discharge in Imperial County were more likely to be covered by Medi-Cal (state government assistance for qualified low-income individuals) than children in San Diego County (66.5\% vs. $53.1 \%, P<0.001)$. Imperial County children were less likely to have private health insurance than San Diego County children (30.9\% vs. $40.7 \%, P<0.01)$.

\section{Trends in air quality parameters}

Ozone. From 1983 through 1994, San Diego County failed to meet both federal (12 pphm) and state (10 pphm until 1987; 9 pphm after 1987) air quality standards for ozone (Figure 2). Imperial County failed to meet federal standards after 1990 and state standards after 1987. Although maximum ozone levels were higher in San Diego County than Imperial County every

FIGURE 2. Maximum and mean levels of ambient ozone, California border counties, 1983-1994

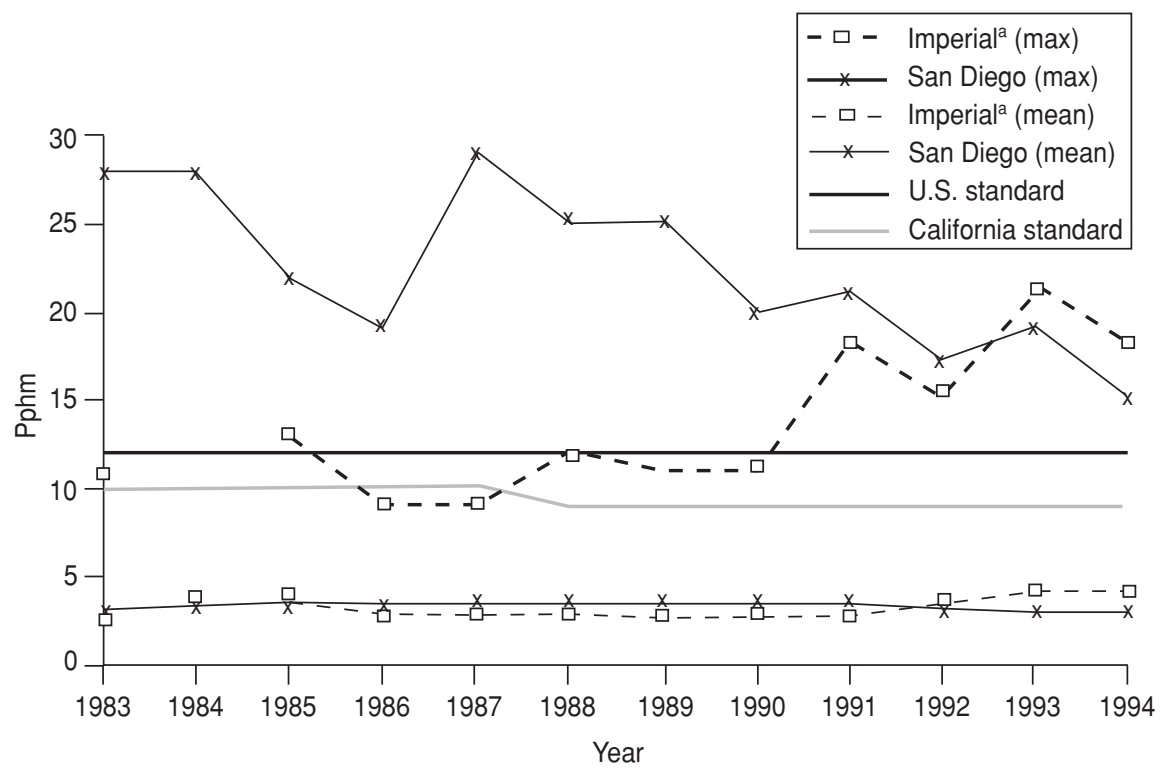

Source: California Environmental Protection Agency, Air Resources Board. a Ozone monitoring was incomplete in Imperial County in 1964.

year until 1993, they decreased $46 \%$ in San Diego County over the time period, while increasing 64\% in Imperial County. However, the apparent increase in maximum ozone levels in Imperial County occurred in 1991, the same year that ozone monitoring began at the international border. A second monitor at the border in Imperial County, although less robust due to fewer sampling points, has shown maximum levels 25-64\% higher than in the county seat since 1991. Mean ozone levels remained fairly stable over time in both counties, although they have started to increase in the last 3 years in Imperial County. The relatively few monitors operating in Imperial County during the 12 -year period makes it impossible to perform a reliable analysis of the trend in maximum and mean ozone levels, although it is evident that they have not decreased.

The average annual number of days per monitor with ozone levels above the Federal ambient air standard showed a similar general improvement in ozone levels in San Diego County, with the number of days showing lev- els above 12 pphm decreasing 88\% over the time period (Figure 3). Imperial County again showed a large increase in the number of days violating the Federal standards after border monitors were installed in 1991.

Particulate matter. San Diego County met the established Federal air quality standards for $\mathrm{PM}_{10}\left(150 \mu \mathrm{g} / \mathrm{m}^{3}\right)$ from 1987 to 1994 , but failed to meet state standards $\left(50 \mu \mathrm{g} / \mathrm{m}^{3}\right)$ after 1984 (Figure 4). Between 1984 and 1994, maximum PM 10 levels in San Diego County more than tripled, and the proportion of $\mathrm{PM}_{10}$ samples above the state standard, while fluctuating, showed a 30\% increase over the same time period (Figure 5). The increase in 1993 in both maximum levels and sample proportions above the state standard was due to the addition of a new $\mathrm{PM}_{10}$ monitor at the international border, which registered high levels.

Imperial County failed to meet both Federal and state $\mathrm{PM}_{10}$ standards every year except in 1987 and 1992, when Federal standards were met (see Fig- 
FIGURE 3. Annual number of days (per monitor) with ambient ozone above $12 \mathrm{pphm}$ (U.S. standard), California border counties, 1983-1994

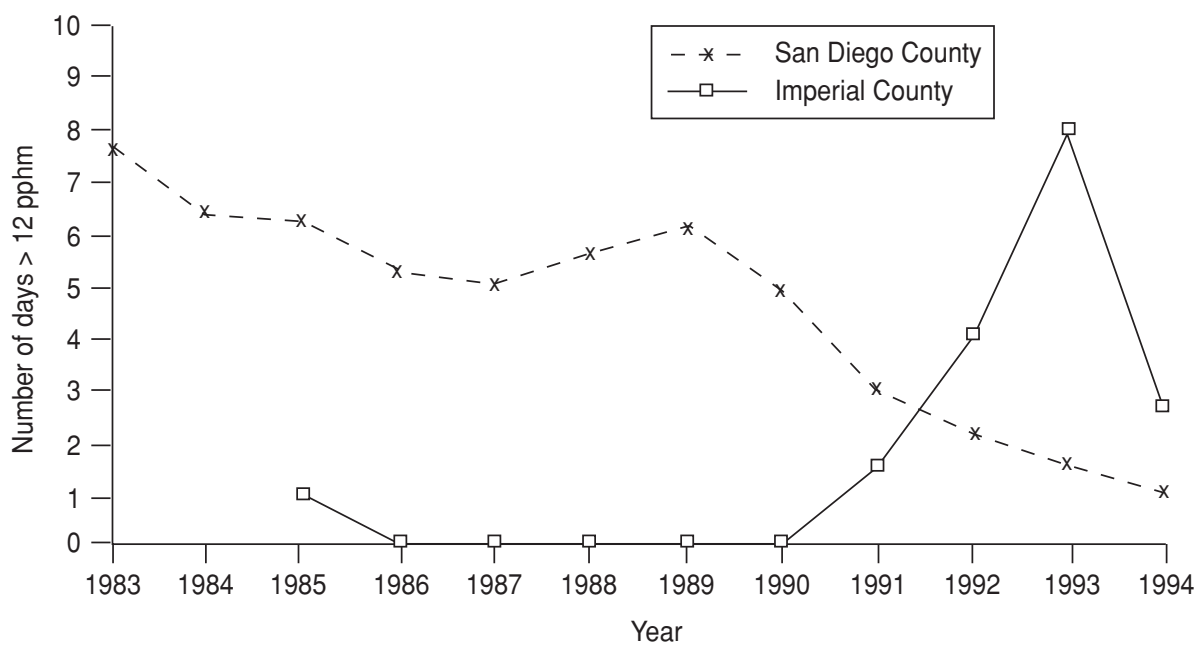

Source: California Environmental Protection Agency, Air Resources Board.

FIGURE 4. Maximum 24-hour average $\mathrm{PM}_{10}$ levels, California border counties, 1983-1994

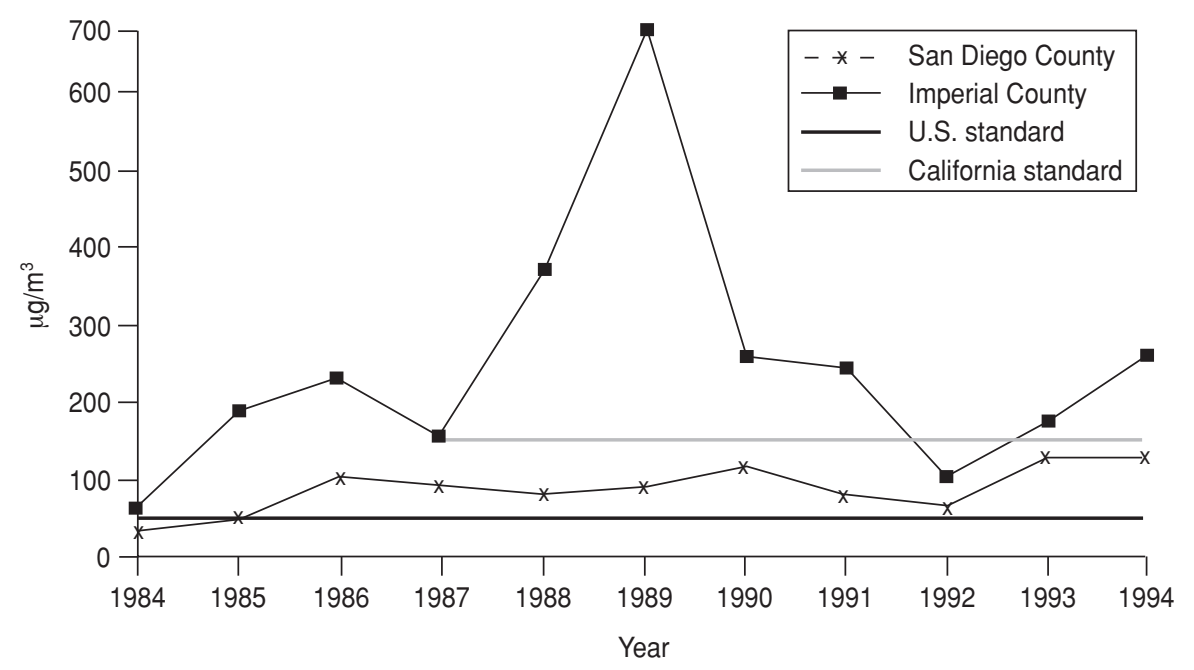

Source: California Environmental Protection Agency, Air Resources Board.

ure 4). From 1984 to 1994, maximum $\mathrm{PM}_{10}$ levels in Imperial County fluctuated, with a dramatic peak in 1989. Levels at the end of the period were four times higher than in 1984. The proportion of $\mathrm{PM}_{10}$ samples above $50 \mu \mathrm{g} / \mathrm{m}^{3}$ fluctuated over the time period in Imperial County, but remained four times higher, on average, than in
San Diego County (see Figure 5). The proportion of Imperial County samples above $50 \mu \mathrm{g} / \mathrm{m}^{3}$ was 2.5 times higher in 1994 than in 1984. A special crossborder study of the Imperial/Mexicali valleys conducted in 1992-1993 found that $\mathrm{PM}_{10}$ levels in Mexicali, the capital of Baja California, were 30-50\% higher than in the Imperial Valley town of
Calexico right across the border, but northwesterly winds lower the impact of $\mathrm{PM}_{10}$ transport from Mexico (17). Unlike ozone, which is heavily influenced by motor vehicle emissions, the latter were estimated to account for only $10-15 \%$ of $\mathrm{PM}_{10}$ mass, with soilrelated compounds accounting for up to two-thirds of ambient $\mathrm{PM}_{10}$ levels (17).

\section{DISCUSSION}

The passage of the North American Free Trade Agreement (NAFTA) in 1993 has intensified the need to assess for potential environmental health problems that may result from rapid industrialization and contamination along the border. Although higher rates of communicable disease have been documented to exist in U.S. border communities as opposed to the U.S. as a whole (17), there has been a paucity of data on non-communicable conditions, such as cancer, adverse reproductive outcomes, and respiratory illness, that may be related to environmental exposures. We examined two counties on the California/Baja California border to obtain baseline data on trends in hospitalizations of childhood asthma. We also examined temporal trends over the same time period for ambient levels of $\mathrm{PM}_{10}$ and ozone, two pollutants that are known to aggravate asthma.

Although childhood asthma hospitalization rates in San Diego County decreased throughout the period 1983-1994, Imperial County rates were two to three times higher than the California average throughout the period (185/100 000 for 1991-1994) and increased dramatically, especially after 1989. Imperial County's rates were the highest of any county in the state for non-Hispanic white and AfricanAmerican children, and the second highest for Hispanic children. In 1993, Imperial County hospitalization rates for childhood asthma were 627/ 100000 , over twice the U.S. average of $280 / 100000$ for the same year (1).

There are several possible explanations for these very high rates of childhood asthma hospitalization. First, 
FIGURE 5. Proportion of samples with $\mathrm{PM}_{10}$ levels above $50 \mu \mathrm{g} / \mathrm{m}^{3}$ (California standard), California border counties, 1984-1994

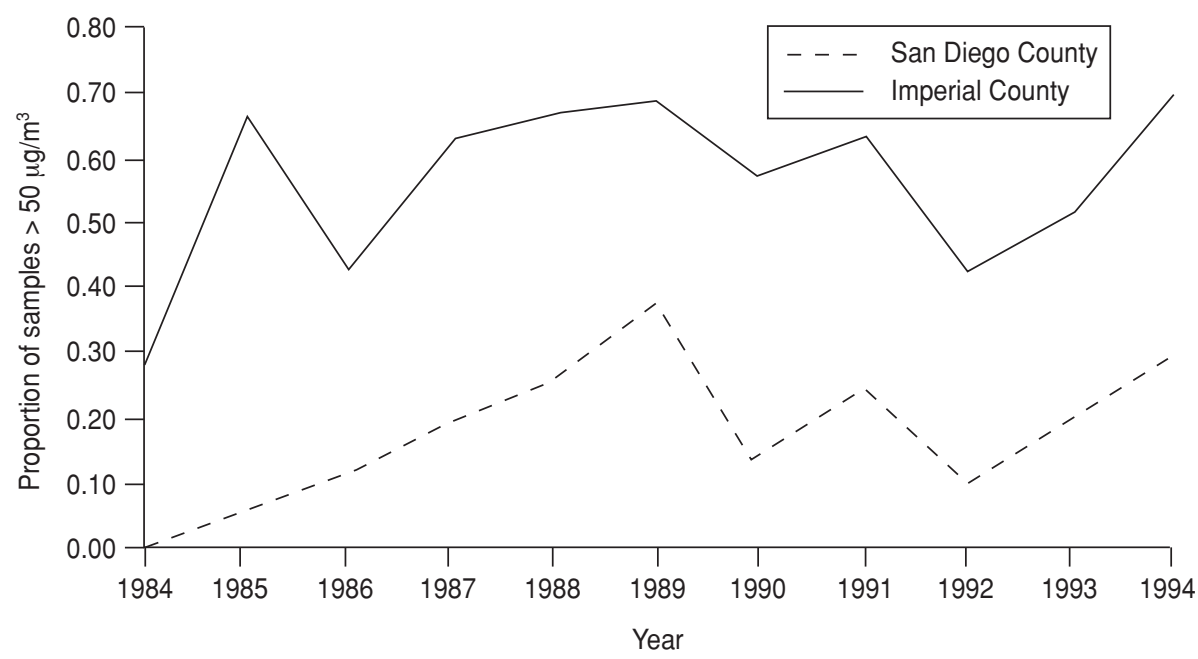

Source: California Environmental Protection Agency, Air Resources Board.

poverty is likely to play a role. Hospitalizations for childhood asthma have been associated with poverty in Maryland (18), and household income was a significant predictor of small area hospitalization rates in New York City (19). Compared to San Diego County, Imperial County has approximately twice the proportion of children under 6 years of age below the Federal poverty level, and its unemployment rates are over four times higher (20). According to the most recent data we examined, Imperial County children with asthma diagnoses at hospital discharge were more likely than similar children in San Diego County to have government assistance and lack private health insurance. It is known that poor children are more likely to receive care in an emergency room than the non-poor (7). Children in Imperial County are probably less likely to receive regular preventive care for asthma than their counterparts in San Diego County. For these children, the emergency room may be the primary source of treatment when respiratory difficulties occur as part of an asthma attack. The rates examined here, however, are limited to cases of severe asthma requiring hospital admission.
Secondly, Hispanic children's high hospitalization rates in Imperial County could be due to an undercount of the number of documented and undocumented Hispanic immigrants in the county. However, undercounting is probably also a problem in San Diego County, where hospitalization rates are low. The California State Department of Finance estimates county populations using a variety of methods, including changes in school enrollments and births, and address changes on drivers' licenses (21). Although these estimates are subject to error, estimates of undocumented immigrants are added to county totals. In addition, the Department of Finance has estimated that their county totals are most likely an overcount of the true population, due to failure to account for greater out-migration than anticipated. This would result in an underestimation rather than an overestimation of our rates.

In the U.S., hospitalizations for asthma have increased primarily among children under 5 years of age. The same is true in Imperial County, but such hospitalizations have also shown an increase in all other pediatric age groups. In San Diego County, only infant rates have been increasing. Consistent with nationwide trends, African-American children were at the highest risk for asthma hospitalization in both counties. As non-Hispanic white and Hispanic children have similar hospitalization rates statewide, it is not clear why white children have higher hospitalization rates than Hispanic children in Imperial County.

Hospitalization for asthma occurs in acute cases and is not a measure of asthma prevalence or incidence. Therefore, we do not know if the high asthma hospitalization rate in Imperial County is a reflection of higher asthma prevalence. In a survey of 654 innercity Hispanic youth in San Diego, California, Christiansen et al. found a prevalence rate of $14.4 \%$ for probable cases of asthma and an additional rate of $13.5 \%$ for possible cases (22). This high prevalence [compared to national data (3)] suggests that pockets of high risk for asthma morbidity are likely to exist wherever poor children reside and access to preventive care is restricted. There is an urgent need for information on asthma prevalence in communities along the entire U.S./ Mexico border.

In San Diego County, ambient ozone levels have been improving while particulate matter levels continue to be high, especially at the border. That ozone levels have decreased in spite of increased traffic can be credited partly to regulatory controls, such as inspections, fuel reformulations, and stationary source compliance. Maintenance of these air quality levels as population and commerce continue to grow will continue to challenge regulators at the border. The slight decrease in childhood asthma rates in San Diego County may or may not be related to the decrease in ambient ozone levels. Despite the improvements, the latter continue to violate federal and state ambient air standards. Hospital admissions for childhood asthma have been found elsewhere to be associated with ozone levels even below the California state standards (23).

Ambient ozone and $\mathrm{PM}_{10}$ levels continue to be an issue of major concern in Imperial County as well. $\mathrm{PM}_{10}$ pollu- 
tion has been associated with respiratory hospital admissions in children in Utah (24) and Canada (25). Exposure to fine particles has been related to school absences (26) and depressed lung function in asthmatic children (27). We found no evidence of improvement in levels of either $\mathrm{PM}_{10}$ or ozone in Imperial County, where childhood asthma rates have increased dramatically. Since spatial coverage of pollutant monitoring has only recently been extended to include the border, we are unable to make definitive statements regarding county-wide trends in ambient air quality, although it is apparent that it has not improved. Since the number of border crossings has increased in recent years and is likely to continue to do so under NAFTA, the burden on the local airshed will also increase unless binational controls are implemented.
In summary, our study of childhood asthma hospitalization rates in two California border counties revealed that Imperial County had extremely high rates that were, on average, two to three times higher than the state and Federal rates. A U.S. Healthy People 2000 objective for environmental health is to "reduce asthma morbidity, as measured by a reduction in asthma hospitalizations, to no more than 225 per 100000 in children aged 14 and younger" (28). While San Diego County has already achieved this objective, if present trends continue, Imperial County is unlikely to do so by the year 2000. In border areas with high poverty rates, such as Imperial County, improved access to preventive health care is imperative. Along the entire border, efforts should be made to reduce the exposure of children to sources of ozone and particulate mat- ter, such as dust from unpaved roads and motor vehicle emissions, which may aggravate respiratory illness. In addition, binational time series studies examining daily ozone and particulate matter readings and hospital admissions during episodes of high pollution should be undertaken to examine asthma-pollutant relationships.

Acknowledgments. This publication was made possible by grant number R01-ES07990-01 from the National Institute of Environmental Health Sciences in Research Triangle Park, North Carolina, USA. The authors would like to acknowledge Frank Carroll's contributions to the air quality analysis. Rick Kreutzer, Michael Lipsett, Peggy Reynolds, and Dan Smith made helpful comments.

\section{REFERENCES}

1. United States of America, National Center for Environmental Health, Division of Environmental Hazards and Health Effects. Asthma mortality and hospitalization among children and young adults-United States, 1980-1993. MMWR 1996;45(17):34-35.

2. Annual Hospital Discharge Database [database]. Sacramento, California: Office of Statewide Planning and Development; Patient Discharge Data Program. (Magnetic tape).

3. Weiss KB, Gergen PJ, Wagener DK. Breathing better or wheezing worse? The changing epidemiology of asthma morbidity and mortality. Annu Rev Public Health 1993;14: 491-513.

4. Salas Ramírez M, Segura Méndez $\mathrm{NH}$, Martínez-Cairo Cueto S. Tendencia de la mortalidad por asma en México [Asthma mortality trends in Mexico]. Bol Oficina Sanit Panam 1994;116(4):298-306

5. Weiss KB, Gergen PJ, Hodgson TA. An economic evaluation of asthma in the United States. NEJM 1992;326:862-866.

6. Koren HS. Associations between criteria air pollutants and asthma. Environ Health Perspect 1995;103(Suppl 6):235-242.

7. Malveaux FJ, Fletcher-Vincent SA. Environmental risk factors of childhood asthma in urban centers. Environ Health Perspect 1995; 103(Suppl 6):59-62.

8. Etzel R. Indoor air pollution and childhood asthma: Effective environmental interven- tions. Environ Health Perspect 1995;103(Suppl 6):55-58.

9. Ganster P. Southwest Center for Environmental Research and Policy. Environmental issues of the California-Baja California border region. Border Environ Res Rep 1996;1.

10. Sweedler A, Ganster P. Sources of air pollution along the border: analysis of data, databases, and information. Final report. San Diego, California: Southwest Center for Environmental Research and Policy; 1997.

11. California Air Resources Board, Aerometric Data Division. California air quality data. Annual summaries, 1983-1994. Sacramento, Ca: CARB; 1995.

12. United States Department of Health and Human Services, U.S. Public Health Service. International Classification of Diseases. 9th revision. Washington, D.C.: DHHS; 1989. (Document number PHS/89-1260).

13. California Department of Finance, Demographic Research Unit. Population estimates of California cities and counties. Sacramento, California: CDF; 1995.

14. Lilienfeld AM, Lilienfeld DE. Foundations of epidemiology. 2nd edition. New York: Oxford University Press; 1980.

15. Miettinen OS. Theoretical epidemiology. New York: John Wiley and Sons; 1985. pp. 137-139.

16. United States of America, Environmental Protection Agency. Imperial Valley/Mexicali cross border $P M_{10}$ transport study. San Francisco: EPA; 1995. (Document DRI/8623.2D1).

17. U.S.-Mexico Border Health Associaton, Pan American Health Organization. Sister communities health profiles: United States-Mexico border, 1989-1991. El Paso, Texas, October 1994.

18. Wissow LS, Gittlesohn AM, Szklo M, Starfield B, Mussman M. Poverty, race, and hospitalization for childhood asthma. AJPH 1988;78: 777-782.

19. Carr W, Zeitel L, Weiss K. Variations in asthma hospitalizations and deaths in New York City. AJPH 1992;82:59-65.

20. California Department of Health Services. Health data summaries for California counties, 1996. Sacramento, California: CDHS; 1996.

21. California Department of Finance, Demographic Research Unit. Population estimates of California cities and counties. Sacramento, California: CDF; 1990.

22. Christiansen SC, Martin SB, Schleicher NC, Koziol JA, Matthews KP, Zuraw BL. Current prevalence of asthma-related symptoms in San Diego's predominantly Hispanic innercity children. J Asthma 1996;33(1):17-26.

23. Bates DV. The strength of the evidence relating air pollutants to adverse health effects. Carolina environmental essay series. Chapel Hill: University of North Carolina Institute for Environmental Studies; 1985. 
24. Pope CA III. Respiratory hospital admissions associated with $\mathrm{PM}_{10}$ pollution in Utah, Salt Lake, and Cache Valleys. Arch Environ Health 1991;46:90-97.

25. Thurston GD, Ito K, Hayes CG, Bates DV, Lippmann M. Respiratory hospital admissions and summertime haze pollution in Toronto, Ontario: consideration of the role of acid aerosols. Environ Res 1994;65:271-290.
26. Ransom MR, Pope CA III. Elementary school absences and $\mathrm{PM}_{10}$ pollution in Utah Valley. Environ Res 1992;58:204-219.

27. Koenig JQ, Larson TV, Hanley QS, Rebbolledo V, Dumler K, Checkaway H, et al. Pulmonary function changes in children associated with fine particulate matter. Environ Res 1993;63:26-38.
28. U.S. Department of Health and Human Services, U.S. Public Health Service. Healthy People 2000: national health promotion and disease prevention objectives. Washington, D.C.: DHHS 1991. (Document PHS/91-50212).

Manuscript received on 5 November 1997. Revised version accepted for publication on 20 February 1998.

RESUMEN Desde que se firmó el Tratado de Libre Comercio en 1993, ha aumentado la necesidad de monitorear problemas de salud que podrían relacionarse con la rápida industrialización de la frontera mexicana-estadounidense. Estudiamos dos condados de la

\section{El asma infantil en la frontera mexicana-estadounidense: hospitalizaciones y calidad del aire ambiental en dos condados de California}

fontera entre California y Baja California con objeto de obtener datos de base sobre las tendencias observadas de 1993 a 1994 en las hospitalizaciones por asma en la infancia y sobre dos sustancias contaminantes que empeoran el asma: el ozono y las partículas en suspensión (de menos de 10 micras de diámetro). Se examinaron los registros de egresos hospitalarios de niños menores de 14 años y las tasas por condado, raza y sexo se ajustaron por edades a la población del estado de California en 1990. Para el ozono y las partículas en suspensión se usaron cinco índices obtenidos de la Agencia Californiana para la Protección del Medio Ambiente (California Environmental Protection Agency). El condado Imperial tuvo las tasas más altas de hospitalización por asma en niños blancos no hispanos y afroamericanos de todo el estado de California, y las segundas más altas del estado en niños hispanos. El condado de San Diego tuvo tasas inferiores al promedio estatal. Durante el período estudiado, las tasas del condado Imperial aumentaron 59\%, mientras que las del condado de San Diego bajaron 9\%. Las concentraciones máximas de ozono aumentaron $64 \%$ en el condado Imperial, pero se redujeron $46 \%$ en el condado de San Diego. Las concentraciones de partículas en suspensión fueron cuatro veces mayores en el condado Imperial que en el de San Diego. Las altas tasas de hospitalización por asma en niños en el condado Imperial podrían deberse en parte a las condiciones de pobreza y a la calidad cada vez peor del aire por aumento de la carga de contaminación que enfrenta el ambiente local. Hacen falta encuestas para investigar la prevalencia de asma y análisis temporales binacionales que examinen la relación entre esta enfermedad y la presencia de sustancias contaminantes. 